\title{
Carl Ebert: the patron behind the history of the State Opera in Turkey
}

Alaz Pesen*

\section{Introduction}

Recently, more links between Translation Studies and history have been brought to the fore worldwide. More scholars have been coming up with not only analyses of translations but also their translators' individual backgrounds. Inevitably, each background the reader is presented with is but a form of rewriting, i.e. the retelling of a background by an individual, which could be tied up with the fact that all history could also be called rewriting. In short, translation and history could be seen as different forms of rewriting. The common denominator, then, is interpretation. If translation is regarded as the interpretation of a text, studies on translation could be regarded as the interpretation of the interpretation of a text. In a similar vein, history or, rather $a$ history could be considered as an individual interpretation of the background to the interpretation of given texts, which forms the raison d'être of the present study.

Interestingly enough, opera translation in Turkey is a hitherto neglected space the history, or rather $a$ history of which has not been covered in detail from the viewpoint of translation studies so far. Among the few works on opera in Turkey are Cevad Memduh Altar's Opera Tarihi and Refik Ahmed Serengil's Türk Tiyatrosu Tarihi II: Opera Sanatı Ille Illk Temaslarmız [History of the Turkish Theatre II: First Contacts with the Opera Genre], which lack a detailed approach to the background of the translated librettos.

\footnotetext{
* Boğaziçi University.
} 
The aim of the present study is to establish a link between translation, opera and musical history, demonstrating that the first Opera librettos to be translated and performed by the State Opera in early republican Turkey were planned and made under the patronage of Carl Ebert, a professional musician designated by the government as part of its cultural planning. These librettos, which were translated by musician-translators under the guidance of Carl Ebert, soon turned into performances, and this helped a great deal in introducing the opera genre into the Turkish Cultural Repertoire and in the construction of the State Opera performance hall in the late1940s.

\section{Methodology}

In this paper, a theoretical framework will first be sketched out to broaden the perspective on the web of relations present in the history of opera translation in Turkey. In applying such framework, the study will heavily rely on first-hand resources: personal correspondence and newspaper articles. Excerpts from Carl Ebert's reports delivered to Hasan Âli Yücel, thenminister of education, will be analyzed with a focus on discourse on the making of the cultural repertoire, Carl Ebert's role as a patron, as well as his plans on making imports. The next part, quoting extensively from newspaper articles of the period, will draw on the opera translations and performances carried out and staged under the patronage of Carl Ebert.

\section{Theoretical Framework}

Even-Zohar maintains that "culture repertoire" is something which need to be "made, learned and adopted by people" (2002, p. 168). Certain people might be deliberately engaged in [building up a cultural repertoire]. There are two "procedures of making repertoire": "invention" and "import" (Even-Zohar 2002, p. 169). It is stated that the latter "has played a much more crucial role in the making of repertoire" (ibid. 2002, p. 169). Translation can be regarded as a type of import, a means of borrowing from the repertoire of another group of people speaking a different language. Therefore, translated works from other languages can develop the repertoire of a 
given culture. In this way a new genre can be introduced into a given repertoire. Moreover, just as translation is a type of import, i.e. something derivative, and as imports might lead to inventions, translation might also give rise to works which are similar to the works translated into the repertoire, in other words, inventions. To put it in Lefevere's words, "One of the most obvious functions of translation, and at the same time a function which translation alone is able to perform satisfactorily, is that of enriching both the target language and the literature written in it" (1975, p. 105). "Enriching the target language and the literature written in it" underscores the formative role translation could assume, giving rise to inventions:

\footnotetext{
The literature written in the target language benefits through [...] new genres [...] Therefore the translator will have to know where the "gaps" in his own national literature are, and he will also have to know where he can find suitable material with which to "stop" them [...] He becomes his national literature's "antenna", picking up new and unfamiliar sounds. (Lefevere 1975, p. 105)
}

While Even-Zohar draws on how imports or translations can assume a formative role, Lefevere places more emphasis on the agent, i.e. the translator. The role of detecting what her/his literature and/or culture lack, that of knowing where to find what the given culture and literature lack, then, might result in filling in the particular "gap" Lefevere mentions. I would like to argue throughout the present study that this role can also be attributed to a patron rather than a translator, namely Carl Ebert. Given the opera translations into Turkish, belonging to a culture other than the target one, Ebert does not act within the target system as a translator, but as a power holder, along with other government authorities. This stems from the fact that he has the authority to "further or hinder the [translation] of literature", a feature attributable to a "patron," for "it is the patron who grants authority to the rewriter with regards to" the way literature is to be shaped, i.e. which works are to be translated and how they are to be translated (Lefevere 1992, p. 15). In the present study, such works happen to be opera librettos to be translated under the patronage of Carl Ebert, an au- 
thority capable of rewarding translators who translated source texts determined by Ebert into Turkish, again in a way approved of by him.

\section{Carl Ebert's Reports}

Among the most important documents regarding the history of opera translation in Turkey are Carl Ebert's reports filed in March 1939. The need to translate the masterpieces of dramatic literature into Turkish is among the concerns Ebert articulates to Hasan Âli Yücel, then-minister of education: "I am writing to ask you to initiate a translation contest that will enable world literature classics to be transferred into Turkish in a perfect manner" (Halıc1 2009, p. 27). ${ }^{1}$ The reasons for his recommending translation, or rather, translations of perfect quality, are enumerated in the report as follows:

\footnotetext{
The learning and reading needs of not only drama students but also drama circles in Turkey are affected by the lack of truthful staging of world drama masterpieces. Most significant works either have not been translated into Turkish at all or those that have been translated are considered to be of very poor quality. (ibid. 2009, p. 27). ${ }^{2}$
}

Apparently, Ebert deems translation beneficial not only to students of the theatre school but also to public in general. It is stated that either the lack of translations of quality, as well as certain works which have not been translated prevent both the students and the public from accessing works of world theatre. In Even-Zohar's terms, the Turkish cultural repertoire is to be built up by means of translating from works of world theatre into Turkish language so that the general public can keep up with other cultural repertoires as a result of such imports. In the same report, reasons for low quality translations and lack of translations are also provided:

One of the main causes of this situation is the inadequate number of valuable theatres in Turkey, which makes it impossible for translators to get

\footnotetext{
${ }^{1}$ Şaduman Halıcı's book includes both the original reports in German filed by Ebert concerning his observations and suggestions, as well as the translations thereof.

${ }^{2}$ My translation. Unless otherwise stated, all translations in the present study are mine.
} 
practical results from their work. Most translations have been "made-toorder" at short notice causing them to be realized in a very short time without showing the necessary attention. (Halıc1 2009, p. 27)

One of the reasons behind translators' being unable to come up with successful translations is the low number of theatres which are of artistic value, leading to a low number of performances to be based on these translations. In other words, the target texts which were supposed to be performance-oriented could not achieve success because there was no platform to perform them. In other words, without room for experimenting on how to perform texts, it would be "impossible" to come up with performable translations. It is also asserted that most of the then-existing translations were made over a short period of time, another reason for the lack of quality.

Before moving on to a detailed plan on how to come up with high quality translations, Ebert underscores the major goal to be pursued: "The interaction among various cultures can contribute a great deal to the rise of a national literature" (Halıc1 2009, p. 27). It is stated in Ebert's discourse that interaction between cultures plays a key role in the coming into existence of a national literature, or in Even-Zohar's terms, a cultural repertoire. Ebert also gives examples of how useful translations can be in the course of developing a cultural repertoire:

Here, I will be referring to German literature's moves, which had crucial results through two significant translations: a) Luther's translation of the Bible; b) Schlegel and Tieck's translations of Shakespeare's works. (ibid. 2009, p. 27)

While the former can be regarded as "the cornerstone of the Reformation in Germany" (Berman 1992, p. 25), the latter as "national treasures which have been a turning point of the time":

As an example, I will be dealing with the "Sturm und Drang" movement in German literature. This movement owes its most significant moves to Schlegel-Tiecks's translations of Shakespeare, which became a national fortune at the time. (Halıc1 2009, p. 28) 
The idea of translated works paving the way for the development of the national literature and theatre could also be regarded, from the vantage point of Even-Zohar, as imports building up a cultural repertoire, along with the inventions such imports will potentially lead to. Ebert seems to have been well aware of such a way of building up the Turkish cultural repertoire. Furthermore, not only does Ebert suggest that imports in the form of translations should be introduced into the repertoire, but also he borrows, or in other words, imports such a strategy of benefiting from imports. Giving as example the imports made by the translators Luther and Schlegel-Tieck into the German cultural repertoire, Ebert formulates a plan to import from world literature into the Turkish cultural repertoire. In short, Ebert can be regarded as a culture planner who not only envisages imports, but also one who comes up with an "imported" idea of imports.

Having set out the reasons for the potential of translating into the Turkish repertoire, Ebert proposes a five-year translation plan:

I will take the liberty to arrange a five-year translation plan and present it to your Excellency. Out of the fifteen works on the list, which have never been translated or have been poorly translated, three can be announced for contest each year. Apart from this and so as to handle the issue immediately, I offer the following three contests to be held:

1- A new translation of Shakespeare's Hamlet. The translation is to be submitted in eight months (the deadline to be January 1940).

First Prize: 500 Turkish lira

Consolation prize: 100 Turkish lira

2- A new and whole translation of Faust's chapters one and two. No rhymes at line-ends. The translation is to be submitted in one year (the deadline to be April 1, 1940).

Prize: 1000 Turkish lira

3- Revision of Ahmet Vefik Paşa's translation of Molière's complete works. Rather than organizing a contest, a translation commission might be appointed to do the revision. The various tasks will be distributed among the members of the commission, which will be checking on each other. This work should be announced right away benefiting from the government's all kinds of publication facilities. The publication and representation right of the works that have won a 
prize is granted to the state. The state owns the right of purchasing works that have not won any prizes, but might be useful. (Halıc1 2009, p.28-29)

In the excerpt, Ebert suggests the idea of a translation contest to enhance the quality of future translations. In addition, a revision of Ahmet Vefik Paşa's translations is proposed. Such a task is to be undertaken by a translation commission to be appointed. What Ebert proposes to Hasan Âli Yücel is the planning of translatorial activity by the government. All these could be interpreted from the perspective of Lefevere's notion of patronage. As a patron, in other words, an authority appointed by the government, Ebert decides on the source texts to translate from, and asks the government to reward the translators who are able to create target texts of desired quality. After all, it is the patron who grants authority to the translator with regards to the selection and the quality of the translation (Lefevere 1992, p. 15). Emphasizing the formative role translation could assume in building up a cultural repertoire, the reports on translation presented to Hasan Âli Yücel by Carl Ebert in March 1939 would also give rise to the first opera translation to be performed by the state opera more than a year later.

\section{Opera Translations under the Patronage of Carl Ebert}

\section{Madame Butterfly}

The Cumhuriyet Newspaper dated June 27, 1940 heralded the first opera performances staged by students of the state conservatory:

\footnotetext{
State Conservatory students' first opera performance was a surprising success. On the night of the first performance, some opera lovers had to confess that they had not expected such a success. Karl Ebert, the director, attributed this success to the talent inherent in the nation, saying "no other conservatory under the sun has made actors/actresses in such a short time out of youngsters who have not seen any operas in their lifetimes." The students performed the second act of Madame Butterfly. (Cumhuriyet 1940, June 27)
} 
What this news article lacked, though, was the fact that Madame Butterfly had been performed in Turkish. In other words, the first opera to be performed by the students of the state opera in the history of Turkish Republic was a translation. As discussed above, stage director Carl Ebert had presented reports to Hasan Âli Yücel on the importance of translation in building up a cultural repertoire and its formative potential. Bearing these in mind, the fact that the first performance by the State Opera in Turkey was a translation was probably more than a coincidence and a result of the correspondence between the two patrons who apparently regarded translation as a way to introduce the genre of opera into the Turkish cultural repertoire.

The libretto had been translated into Turkish by Necil Kazım Akses, Hasan Ferit Alnar and Cevad Memduh Atlar, who were not only translators but also musicians. Necil Kazım Akses was a violin player and a composer trained in Austria. Hasan Ferit Alnar was a kanun player and a composer trained in Austria, and in 1945 he would be the conductor of the Presidential Philharmonic Orchestra. Cevad Memduh Atlar was also a violin and viola player and an art historian. All of these musicians had in common a background in Western music, which made them assets to the shaping of opera literature envisaged by Ebert. Under his patronage, these musicians were to go down in history as the translators of the first opera performed by the students of the State Opera, a milestone in the history of opera translation. The next opera performed by the students of the State Opera was also translated by Ferit Alnar, but this time, alone.

Tosca

Ferit Alnar's translation of Puccini's Tosca was broadcast live on the Ankara Radio on April 2, 1941. The performance, just like Madame Butterfly, was performed in the community center in Ankara, for the conservatory did not have a concert hall of its own. In his article in Cumhuriyet dated April 4, 1941, Nadir Nadi praised the performance by the students of the State Opera and expressed his amusement for an orchestra made up of Turkish musicians and opera singers: 
Imagine we attend an opera performance in the heart of Anatolia. Imagine the cast are Turkish and they sing in Turkish in the accompaniment of an orchestra of Turkish musicians. Who could believe? The fellow-citizens who were tuning the radio for music must have not believed their ears and thought that they chanced upon a middle European radio channel when they heard the second act of Tosca on the Ankara radio station. (Cumhuriyet 1941, April 4)

What was even more striking about the performance was that in the days the Second World War loomed the world, the most authoritative figure in Turkey after Atatürk's death, President İsmet İnönü had attended the performance, a fact highlighting his support for the newly-introduced genre. In other words, this was the first opera translation in Turkey attended by President İnönü, and as the then-most powerful patron in Turkey, such attendance could be interpreted as reaffirming in public his support for the translations initiated by another patron, Carl Ebert. With the boosted support, the media began showing more interest in him. Here is an excerpt from Ebert's comments which appeared in Cumhuriyet dated April 13, 1941 - eleven days after Toska had been performed:

\footnotetext{
What impressed me [in Turkey] was the boundless interest that your regime showed in art. I worked really hard to spread art as a culture in Germany, where art is already a part of the culture. [In Turkey], however, the state opened courses for free enabling people to improve their talents easily. (Cumhuriyet 1943, April 13)
}

The interest shown by patrons such as İsmet İnönü and Hasan Âli Yücel in opera was not something Carl Ebert was accustomed to in Germany where he had put in a great deal of effort to find a patron to start an art school. Nevertheless, despite the patronage of government officials in Turkey, there was a long way to go:

However, now I will mention some failures. First of all, we do not have a stage. This building, which was built as music teacher's training school, 


\begin{abstract}
does not meet our needs. We do not have a ballet-dancer, which is, as you should know, an essential element in an opera. Our choir is also very poor and elementary. And the most significant of all: Literature! Turkish writers and poets do now write plays. All of the works we teach the students are translations. However, you need national works to have a national stage. Still, these failures are not necessarily irredeemable. A proper building will be provided in the future and your writers, who will continue to see successful performances, will feel the need of writing plays. These are all linked to one another. (Cumhuriyet 1943, April 13)
\end{abstract}

What Carl Ebert had in mind, even when his reports were presented to Hasan Âli Yücel in 1939, then, was translation for the sake of original operas and theatres composed by Turkish artists. This was the ultimate goal. Carl Ebert encouraged imports to pave the way for inventions. Ebert probably regarded imports, or in other words, translations under his and Hasan Âli Yücel's and İsmet İnönü's patronage as assuming temporary but key function in introducing the genre into the target repertoire. Nevertheless, there was more to it. The national opera and theatre literature he had in mind could only be formed by national opera and theatre works, but, first of all, a hall of sufficient quality should have to be built to enable more successful performances. Only then the playwrights or future playwrights among the audience would take the pains to come up with inventions. In short, each and every one of these items was, or, would have to be linked to one another. İnönü and Yücel's support for Ebert could be deemed longlasting. Three months later, the first graduates of the conservatory would be awarded their diplomas by İsmet İnönü. Hasan Âli Yücel who was also present at the ceremony gave a speech, in which he praised Carl Ebert highly. Nevertheless, until a performance hall of desired quality was built, yet-to-graduate students of the State Opera would have to do their best in their performances in the low-quality hall for the time being. Among such performances were Fidelio and Prodana Nevesta. 
Fidelio and Prodana Nevesta

On February 14, 1942, thanks to the translation of Ulvi Cemal Erkin and Necil Kazım Akses, two of the translators of the first opera performed by the students of the State Opera, Ankara would host Beethoven's Fidelio in Turkish, in which a future opera translator would star: Saadet İkesus. In 1941, German media had reported that the young Saadet İkesus, who had a very successful career as an opera singer, would be the pride and joy of German Theatre (Oral 1984, p. 20). At a time when Turkish theatre and opera were eagerly supported by such patrons as İsmet İnönü and Hasan Âli Yücel, this was frowned upon by Turkish bureaucrats in Germany. In the mean time, Carl Ebert was planning to perform Fidelio in Turkey with his students. Saadet İkesus was immediately invited to Ankara both as an opera actress and a singing instructor. Despite the objections of her instructor in Germany, Schultz, she could not turn down the offer. State Opera's performance of Fidelio in the Ankara People's House on February 15 and 16, 1942 was attended by İsmet İnönü and his wife. "The National Leader" would congratulate Saadet İkesus and the other performers in person right after the first performance.

A year later, on February 12, 1943, İsmet İnönü and his wife would attend another performance by the State Opera: Satılmış Nişanlı was translated from the Czech composer Bedrich Smetana's Prodana Nevesta into Turkish by Halil Bedi Yönetken, a musician trained in Czechoslovakia and by Nurullah Taşkıran, a baritone opera singer who acted in the Turkish version of Tosca in Ankara two years earlier, who was also trained abroad. The performance, just like Fidelio, took place subsequent to the Turkish National Anthem ceremony. Hasan Ferit Alnar, the translator of Madame Butterfly and Tosca, was the conductor of the orchestra accompanying the singers. Among other guests were Abdülhalik Renda, then-president of the national assembly of Turkey and other members of parliament. The performance, broadcast both on long-wave and short-wave radio, was followed by İsmet İnönü's encouraging remarks to Carl Ebert, Hasan Ferit Alnar and Halil Bedi Yönetken: 


\begin{abstract}
You have furnished us with a new and beautiful piece of art. Apparently you have prepared very well. All the community admires you hard work. We would like you to see new ones soon. We believe in you. Congratulations to each and every one of you. (Cumhuriyet 1943, February 12)
\end{abstract}

İnönü's remarks, especially "we have gained a new and beautiful work thanks to you" could be regarded as the patron's regarding translated operas as part of the Turkish cultural repertoire. As a patron holding more power, he also congratulated Hasan Âli Yücel, Minister of Education, on the Satılmış Nişanlı performance of the State Opera (Cumhuriyet February 15, 1943): "be proud of your children," another demonstration of the encouragement and support İnönü provides to a patron with less power. Such an encouraging attitude definitely has a positive impact on Carl Ebert, who regards translation as a way of building up the culture repertoire with imports. The support was not made up of praise, and three months later, a performance festival was to be held, and in a period of about a month - that is from May 2, 1943 to June 18, 1943 - during which performances by the State Theatre and Opera would be broadcast on the radio. These performances were again the four opera translations played so far: Madame Butterfly, Tosca, Fidelio and Satılmış Nişanlı, which were described in Cumhuriyet dated May 21, 1943 as "the best examples of the opera genre". Satisfied with the interest shown in the genre, Carl Ebert was determined to stick to his plan:

\footnotetext{
Efforts are being made to have significant works translated in a short time to foster a close collaboration between the conservatory and the translation bureau, which will provide high quality samples for both future Turkish playwrights and actors. (Cumhuriyet 1943, May 21)
}

One more time, he underscored the importance of imported opera works in building up the cultural repertoire, which would pave the way for inventions. As Ebert pointed out in his reports to Hasan Âli Yücel in 1939, translation needed to be taken seriously and collaboration with the state owned translation bureau would increase the probability of imports of desired quality. As discussed above, Ebert had proposed a list of works to be 
translated to Hasan Âli Yücel in 1939. There are grounds to believe that he must have proposed another list later on because in the interview covered in Cumhuriyet dated May 21, 1943, Ebert stated that among the next operas to be translated and performed were Rossini's Il Barbiere di Siviglia, Mozart's Le Nozze di Figaro and Bizet's Carmen. Interestingly enough, the Cumhuriyet newspaper that came out just six days later, on May 27, 1943, reported Hasan Âli Yücel's remarks on education at a meeting in Parliament:

\begin{abstract}
I consider translations of classics as the primary marks of national culture and national arts. We have not yet established a proper theater and opera. We are still at the bottom of the ladder. Just as we do in our schools, we should offer classics in the Conservatory in the form of performances thereof and operas. (Cumhuriyet 1943, May 27)
\end{abstract}

In the same vein with Carl Ebert's remarks on translations and future autochthonous operas, Hasan Âli Yücel was making it clear that just as the translation of world literature would give rise to a national literature, or from Even-Zohar's viewpoint, just as imports would pave the way for inventions, translated opera works would enable "invented" or "national" operas in the long run. To such an end, as patrons, Hasan Âli Yücel and Carl Ebert had undertaken the task of providing the students of the state conservatory with a curriculum made up of translated opera classics.

As discussed above, Ebert also attached critical importance to the building of a concert hall for the opera, along with translations. This would be the State Opera and Theatre Hall in Ankara, which would not be built and opened until April 2, 1949, almost two years after Carl Ebert resigned from his position within the State Opera and Theatre. ${ }^{3}$ Nevertheless, as the actor Jean Marchat would tell Metin Toker in an interview which appeared in Cumhuriyet dated May 2, 1947, Ebert's resignation did not mean his efforts would prove fruitless. In fact, we have historical evidence to the con-

\footnotetext{
${ }^{3}$ In fact, The State Opera and Theatre Hall had opened a year earlier, in April 1948 but then got closed down again due to the fact that it was not yet ready to host performances. In his article which appeared in Cumhuriyet dated April 2, 1949, Lütfi Ay criticizes the authorities for this first opening, and asserts that the Hall could have been opened once and for all at the end of 1948, almost 6 months prior to the final opening, if the authorities had been more patient.
} 
trary. In May 1943, as mentioned above, Carl Ebert had already stated that the next operas to be translated and performed by the State Opera were Bizet's Carmen, Mozart's Le Nozze di Figaro and Rossini's Il Barbiere di Siviglia. The State Opera would stick to Ebert's plans.

\section{Carmen, Le Nozze di Figaro and Il Barbiere di Siviglia}

The same operas would be staged after Ebert's resignation. Carmen would be the first opera to be staged in the State Opera and Theatre Hall, in celebration of the opening of the same on April 2, 1948. This performance had two aspects envisaged by the patron Ebert: (1) the Hall had finally been put up, and (2) one of the translations Carl Ebert announced to be made and performed had been staged. The translators were again Ulvi Cemal Erkin and Necil Kazım Akses. Nevertheless, there were other opera composers/performers in the cast, who at the same time acted as opera translators. The orchestra was conducted by Hasan Ferit Alnar, opera composer and translator, and Saadet İkesus had the starring role. The position of stage director had been taken up by Renato Mordo. Le Nozze di Figaro, translated into Turkish as Figaro'nun Dügünü by Necil Kazım Akses and Ferit Alnar was staged in October 2, 1948. This was followed by the performance of Il Barbiere di Siviglia in April 2, 1949, in celebration of the reopening of the State Opera and Theatre performance hall. Given the importance attached by Carl Ebert in erecting a performance hall for the State Opera for the sake of a cultural opera repertoire also consisting of inventions, it is telling to see that the two translations staged in celebration of the two openings had been formerly selected by him. His absence made it even more interesting, for the two conditions to be satisfied were combined in these two openings: (1) A performance hall of desired quality for the State Opera, and (2) Translation. The third condition Ebert envisaged had also been staged in celebration of the first opening: Ahmet Adnan Saygun's Kerem ile Aslı, a one-act opera with a cast of two opera singers, who also had roles in translations staged by Carl Ebert: Ayhan Aydan and Aydın Gün. Such an early opera written by a Turkish composer, or in Even-Zohar's sense, an invention within the Turkish cultural repertoire, could have been impossible if it were not for the patronage of Carl Ebert and that of Hasan Âli Yücel. 


\section{Conclusion}

After assuming the position of stage director and expert of the State Opera and Theatre in 1936, Carl Ebert acted as a patron highlighting the importance he attached to translation both in his reports to Hasan Âli Yücel and in interviews. The support provided to him by both Hasan Âli Yücel and İsmet İnönü helped him a great deal in succeeding in such a quest. A sign of his being successful in introducing into the repertoire is the fact that the source texts he planned to have translated before resigning from his position in 1947 were translated and performed in the following years. As stated above, among such examples were Carmen, Le Nozze di Figaro and Il Barbiere di Siviglia. Another proof of his long-term influence over the State Opera was the reperformance of the works translated into Turkish and performance even after his resignation. Among such examples were the state opera's (re)performances of Madame Butterfly in 1952, Tosca in 1951 and 1954 and Fidelio in 1952, not to mention the performances of these and other translations initiated under the patronage of Ebert. Another consequence of his efforts was the erection of the State Theatre, temporarily in 1948, and permanently in 1949. A year after Carl Ebert's resignation, the first, to use Even-Zohar's term, "invented" opera, was performed by the state opera, a goal Ebert had always in mind.

It might merely be a matter of coincidence, but there may also be grounds for arguing that just as Ebert might have been influenced by Hasan Âli Yücel with regard to making use of translation in building up a cultural repertoire, the former might as well have influenced the latter. Ebert's report to Yücel in March 1939 might even have contributed to Hasan Âli Yücel's ideas regarding translation and Birinci Neşrıyat Kongresi, the First Printing Congress in May 2, 1939, as a result of which Tercüme Bürosu, Translation Bureau, was founded. As discussed above, in the report delivered to Yücel two moths prior to the congress, Ebert was proposing a planned list of to-be-made translations in a given time, which bore a similarity to some of the points to be addressed at Neşriyat Kongresi, which appeared in Cumhuriyet a month before, on March 29, 1939: 


\begin{abstract}
- Identifying the works, including classics, which need to be translated into Turkish, preparing a timetable and distributing the tasks;

- Deciding on prizes, an effective way of promoting translation in the country, and laying down the criteria for the prizes. (Cumhuriyet 1939, March 29)
\end{abstract}

Paving the way for Translation Bureau, which became active in 1940, the Congress closed on May 5, 1939. Another fact increasing the possibility of the influence of the correspondence between Carl Ebert and Hasan Âli Yücel was that, as Şehnaz Tahir Gürçağlar has pointed out, "the Translation Bureau translated 10 plays which were printed among the publications of the State Conservatory" $(2005$, p. 71$)$. In fact, three years prior to his report presented to Hasan Âli Yücel, Ebert had sent Cevad Memduh Altar, ${ }^{4}$ then-head of higher education institution, a letter including Ebert's intention of making use of translation in introducing the opera genre into the Turkish cultural repertoire. Here is an excerpt from his letter written on May 3, 1936:

\begin{abstract}
A serious lack of good domestic classical drama works and that of good translations of foreign works have constituted an obstacle to the Turkish theater $[. .$.$] To prevent such an obstacle from turning into a mortal risk for$ the new theater reform, this huge deficiency of material in the great and classic drama works should be overcome as soon as possible. However, because it is not an easy task to realize a classic masterpiece [...], what has been neglected up until now in the field of translation should now be compensated. At this point, announcing tempting prizes for the best translations of specific classic plays, the state could take on and help the new Turkish theater make a great leap forward. If this offer is publicized successfully, the young generation of teachers will be immensely enthusiastic about it. New values will be added to the theater, both teachers and actors will learn on the same plane in the field of foreign drama. The people will be pleased to see their horizons expand [...] and all this will help a domestic literature be born. The influence of Schlegel-Tieck's ingenious translations of Shakespeare, which exist in Germany even today, is an obvious example for this claim. This work by itself was enough to create a movement, which would influence all the works of an extended period. (Kazankaya Erten 1985, p. 23)
\end{abstract}

\footnotetext{
${ }^{4}$ Cevad Memduh Altar, also a professional musician, would translate operas in the years that followed.
} 
This last claim might as well be the subject of another study and needs to be explored further. Nevertheless, in the very same letter to Cevad Memduh Altar, together with certain theatrical plays, Carl Ebert also includes a list of opera works to be translated into Turkish: Mozart's Le Nozze Di Figaro, Bizet's Carmen and Verdi's Un Ballo in Maschera.

To recapitulate, as a professional musician with considerable expertise in the opera genre, Carl Ebert both founded the State Opera in Turkey and individually undertook the task of building up the State Opera Repertoire. Influenced by the foundational, or in other words, formative role played by the Lutherian Bible and Schlegel and Tieck's Shakespeare translations in the German cultural repertoire, Ebert made use of his position as a patron - a power holder within the Turkish society - to encourage the way German society made imports. Under his patronage, many musicians began to translate from opera librettos, selected by Carl Ebert. His correspondence with Hasan Âli Yücel, then-minister of education, revealed that the two figures had in common the will to make use of translation in the course of bringing in new genres into the repertoire. Under Ebert's patronage, translations eventually led to performances several of which were attended by İsmet İnönü, even in the days during which the Second World War loomed the world and the Turkish government was striving for maintaining its impartiality, a fact proving the increased popularity and prestige of Carl Ebert and the State Opera, as well as the importance attached to a newly introduced genre such as opera by the government. Such an increased popularity resulted in the construction and opening of the State opera performance hall. Translations made or planned to be made at the time in which Ebert was stage director, along with inventions, went on being staged years after his resignation, which could be interpreted as Carl Ebert's success as a patron with the intention of making use of translation in introducing a new genre into the Turkish cultural repertoire - a blank space in the intersection of translation, music and history the present study has endeavoured to fill in. 


\section{References}

BERMAN, Antoine. L'Épreuve de l'étranger. Paris: Gallimard. Translated from French by S. Heyvaert under the title The Experience of the Foreign: Culture and Translation in Romantic Germany. Albany: State University of New York Press, 1992.

Cumhuriyet Newspaper. May 2, 1947, Istanbul, p. 3.

. May 27, 1943, Istanbul, p. 5. . May 21, 1943, Istanbul, p. 7. . February 15, 1943, p. 5. . February 12, 1943, p. 4. . April 13, 1941, p. 1. . April 4, 1941, p. 4. . June 27, 1940, p. 3. . March 29, 1939, p. 6.

Devlet Opera ve Balesinde Sergilenen Opera ve Baleler (1948 - 1987). Cilt 1. Ankara: Devlet Opera ve Balesi Genel Müdürlüğ̈̈ Yayınları.

EVEN-ZOHAR, Itamar. The Making of Culture Repertoire and the Role of Transfer. In Translations: (Re)shaping of Literature and Culture. Edited by Saliha Paker. İstanbul: Boğaziçi University Pres, 2002, pp. 166-174.

HALICI, Şaduman. Ankara Devlet Konservatuarının Kuruluşu: Prof. Carl Ebert'in Raporları. Ankara: Atatürk Kültür Merkezi Yayınları, 2009. KAZANKAYA ERTEN, Nesrin (tr.). Carl Ebert'ten Mektuplar. Devlet Tiyatroları Yayınları, Belgeler Dizisi 1, 1985.

LEFEVERE, André. Translation, Rewriting, and the Manipulation of Literary Fame. New York: Routledge, 1992.

LEFEVERE, André. Translating Poetry: Seven Strategies and a Blueprint. The Netherlands: Assen, 1975.

ORAL, Zeynep. Hocaların Hocası Saadet İkesus Altan'la Dünden Bugüne. In Milliyet Sanat Dergisi 109: 18 - 21, 62, 1984.

TAHIR-GÜRÇAĞLAR, Şehnaz. Kapılar. Istanbul: Scala Yayıncılık, 2005. 


\begin{abstract}
The first opera librettos to be translated and performed by the State Opera during the early republican period in Turkey were selected by of Carl Ebert, a professional musician of Judeo-German origin, appointed by the Turkish government as part of its cultural planning policies. Filling in a blank space in the intersection of translation, music and history. The present study demonstrates how song translation assumed a formative role in introducing the opera genre into the Turkish cultural repertoire during a period of intensive state-controlled westernization.
\end{abstract}

Keywords: Carl Ebert; Translated opera; History of music; Turkey; State Opera.

\title{
Resumo
}

Os primeiros libretos de ópera traduzidos e encenados pela Ópera do Estado durante o início do período republicano na Turquia foram selecionados por Carl Ebert, um músico profissional de origem judaico-alemã nomeado pelo Governo Turco como parte integrante de suas políticas de planejamento cultural. Preenchendo uma lacuna na intersecção entre tradução, música e história, esta pesquisa procura demonstrar como a tradução de canções assumiu um papel formativo na introdução do gênero operístico no repertório cultural da Turquia durante um período de intensa ocidentalização controlada pelo Estado.

Palavras-chave: Carl Ebert; Ópera traduzida; História da música; Turquia, Ópera do Estado. 